AUTHOR CORRECTION OPEN

\title{
Author Correction: Evolution of HER2-low expression from primary to recurrent breast cancer
}

Federica Miglietta, Gaia Griguolo, Michele Bottosso (D), Tommaso Giarratano, Marcello Lo Mele, Matteo Fassan (iD, Matilde Cacciatore, Elisa Genovesi, Debora De Bartolo, Grazia Vernaci (D), Ottavia Amato (iD, PierFranco Conte, Valentina Guarneri (iD and Maria Vittoria Dieci iD

npj Breast Cancer (2021)7:149; https://doi.org/10.1038/s41523-021-00359-w

Correction to: npj Breast Cancer https://doi.org/10.1038/s41523021-00343-4, published online 12 October 2021

In this article, the affiliation 'Veneto Institute of Oncology IOV IRCCS, Padua, Italy' for Matteo Fassan was missing. The original article has been corrected.

\begin{abstract}
Open Access This article is licensed under a Creative Commons Attribution 4.0 International License, which permits use, sharing, adaptation, distribution and reproduction in any medium or format, as long as you give appropriate credit to the original author(s) and the source, provide a link to the Creative Commons license, and indicate if changes were made. The images or other third party material in this article are included in the article's Creative Commons license, unless indicated otherwise in a credit line to the material. If material is not included in the article's Creative Commons license and your intended use is not permitted by statutory regulation or exceeds the permitted use, you will need to obtain permission directly from the copyright holder. To view a copy of this license, visit http://creativecommons. org/licenses/by/4.0/.
\end{abstract}

(c) The Author(s) 2021 